\title{
AN ANALYSIS OF THE DEPRESSOR RESPONSES TO HISTAMINE IN THE CAT AND DOG: INVOLVEMENT OF BOTH $\mathrm{H}_{1}$-AND $\mathrm{H}_{2}$-RECEPTORS
}

\author{
J.W. BLACK ${ }^{1}$, D.A.A. OWEN \& M.E. PARSONS \\ The Research Institute, Smith Kline and French Laboratories Ltd, Welwyn Garden City, Hertfordshire
}

1 The depressor responses to histamine, in anaesthetized cats and dogs, have been shown to involve both histamine $\mathrm{H}_{1}$ - and $\mathrm{H}_{2}$ - receptors.

2 In both species, histamine caused dose-dependent falls in blood pressure. The dose-response curve could be displaced to the right by administration of mepyramine $2.5 \times 10^{-6} \mathrm{~mol} / \mathrm{kg}$ i.v. The displacement was maximal with a dose-ratio of less than ten.

3 Metiamide alone, up to $2 \times 10^{-6} \mathrm{~mol} \mathrm{~kg}^{-1} \mathrm{~min}^{-1}$, had no significant effect on the histamine dose-response curve.

4 When administered in the presence of mepyramine, metiamide, $4 \times 10^{-7}$ and $2 \times 10^{-6} \mathrm{~mol}$ $\mathrm{kg}^{-1} \min ^{-1}$, caused dose-dependent displacements to the right, of the histamine dose-response curve greater than could be achieved with mepyramine alone.

5 The results indicate the presence of both histamine $\mathrm{H}_{1}$ - and $\mathrm{H}_{2}$-receptors in the cardiovascular system of the cat and dog. Both receptors produce a common response, i.e. a fall in blood pressure.

\section{Introduction}

In 1910, Dale \& Laidlaw reported that histamine caused dose-dependent depressor responses in cats and dogs. The depressor responses to small doses of histamine can be reduced or abolished by the administration of $\mathrm{H}_{1}$-receptor antagonists (Folkow, Haeger \& Kahlson, 1948) although the responses to large doses of histamine are refractory to $\mathrm{H}_{1}$-receptor antagonists (Staub, 1939; Folkow et al., 1948).

Preliminary experiments with the histamine $\mathrm{H}_{2}$-receptor antagonist, burimamide (Black, Duncan, Durant, Ganellin \& Parsons, 1972) showed that the depressor responses to large doses of histamine, which are refractory to $\mathrm{H}_{1}$-receptor antagonists, could be abolished by burimamide. These experiments are consistent with the involvement of both $\mathrm{H}_{1}$ - and $\mathrm{H}_{2}$-receptors in the cardiovascular response to histamine in the cat and dog.

These observations have been extended using the selective $\mathrm{H}_{1}$-receptor antagonist, mepyramine and the selective $\mathrm{H}_{2}$-receptor antagonist, metiamide (Black, Duncan, Emmett, Ganellin, Hesselbo, Parsons \& Wyllie, 1973) and the histamine depressor responses have been analyzed in terms of the receptors involved.

1 Present address: Department of Pharmacology, University College London, London WC1 6BT.
A brief account of some of these data has been presented to the British Pharmacological Society, March 1974 (Owen \& Parsons, 1974).

\section{Methods}

Experiments were performed on cats of either sex, body weight $1.4-2.5 \mathrm{~kg}$, anaesthetized by an intraperitoneal injection of sodium pentobarbitone, $60 \mathrm{mg} / \mathrm{kg}$, and on beagle dogs of either sex, body weight $9.5-12 \mathrm{~kg}$, anaesthetized by an intravenous injection of sodium pentobarbitone, $30 \mathrm{mg} / \mathrm{kg}$. Supplementary doses of sodium pentobarbitone were given as necessary to maintain anaesthesia. In the cats the trachea was cannulated and the dogs were intubated with a cuffed endotracheal tube.

The right femoral artery was cannulated to measure systemic blood pressure with a Statham P23A blood pressure transducer. Blood pressure was monitored on a Devices M8 Electronic recorder. Drugs were administered via cannulae inserted into peripheral veins, usually the right femoral vein and right brachial vein.

\section{Drugs}

Histamine acid phosphate (B.D.H.), mepyramine maleate (May \& Baker), phentolamine methane- 

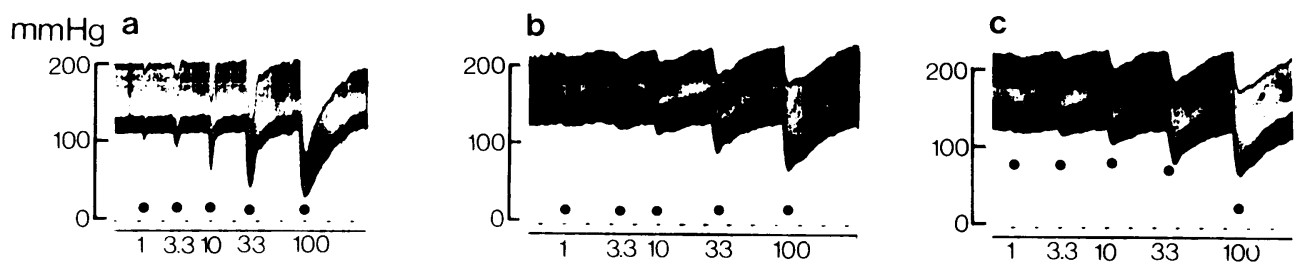

Dose of histamine $\times 10^{-9} \mathrm{~mol} / \mathrm{kg}$
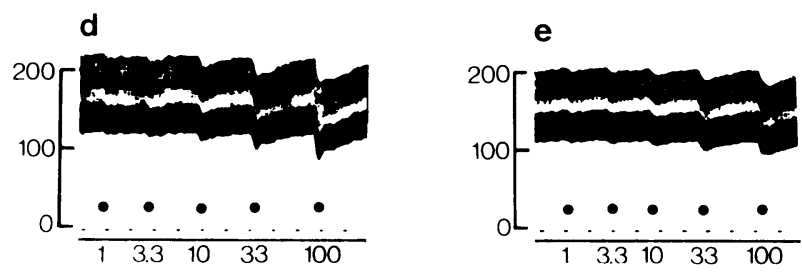

Figure 1 Anaesthetized dog blood pressure. (a) Histamine ( $\bullet$ ) caused dose-dependent falls in blood pressure. (b) The responses were reduced by mepyramine $2.5 \times 10^{-5} \mathrm{~mol} / \mathrm{kg}$ ). (c) Increasing the dose of mepyramine to $5 \times 10^{-5} \mathrm{~mol} / \mathrm{kg}$ caused no further reduction in the histamine responses. ( $\mathrm{d}$ and e) In the presence of mepyramine $\left(5 \times 10^{-5} \mathrm{~mol} / \mathrm{kg}\right)$ metiamide $\left(4 \times 10^{-7}\right.$ and $\left.2 \times 10^{-6} \mathrm{~mol} \mathrm{~kg}^{-1} \mathrm{~min}^{-1}\right)$ caused further dose-dependent reductions in the responses to histamine.

sulphonate (Ciba) and ( \pm )-propranolol hydrochloride (I.C.I.) were prepared as solutions in $0.9 \%$ $w / v ~ \mathrm{NaCl}$ solution (saline). Metiamide solutions were prepared by dissolving the base in a small quantity of $0.1 \mathrm{~N} \mathrm{HCl}$. The $\mathrm{pH}$ of the solution was then raised to 7 by the addition of $0.1 \mathrm{~N}$ $\mathrm{NaOH}$ and the solution finally made up to volume with saline.

Histamine was administered by injection, at intervals of $5 \mathrm{~min}$, in a volume of $0.1 \mathrm{ml} / \mathrm{kg}$ and the venous cannula washed with $0.5 \mathrm{ml}$ of saline. Dose-response curves were made by injection of increasing doses of histamine. Mepyramine, phentolamine and propranolol were administered as single, intravenous injections. Because of its shorter duration of action metiamide was administered by continuous intravenous infusion in volumes of $0.11-0.28 \mathrm{ml} / \mathrm{minute}$. Infusions were made for $30 \mathrm{~min}$ prior to repeating the histamine doses and continued during dosing.

\section{Results}

\section{Anaesthetized dogs}

Histamine administered intravenously caused dose-dependent falls in systemic blood pressure (Figure 1); the threshold dose was about $1 \times 10^{-10}$ $\mathrm{mol} / \mathrm{kg}$. No attempt was made to obtain maximal depressor responses as the blood pressure did not always return to the pre-injection level in control dogs after doses in excess of $1 \times 10^{-7} \mathrm{~mol} / \mathrm{kg}$. Nevertheless a linear dose-response relationship could be obtained over the dose-range $1 \times 10^{-9}$. $1 \times 10^{-7} \mathrm{~mol} / \mathrm{kg}$ (Figures 1 and 2 ).

Administration of mepyramine $\left(2.5 \times 10^{-6}\right.$ $\mathrm{mol} / \mathrm{kg}$ ) caused a parallel displacement to the right of the histamine dose-response curve (Figure 2). Increasing the dose of mepyramine to $2.5 \times 10^{-5}$ or $5 \times 10^{-5} \mathrm{~mol} / \mathrm{kg}$ did not significantly displace the dose-response curve further to the right. Two groups of experiments were made in which the maximum displacement of the dose-response curves occurred with a dose-ratio of 3.2 (3.1-3.5, $95 \%$ confidence limits), in one group and a doseratio of $4.2(2.3-7.4)$ in the second group. When the maximum blocking effect of mepyramine had been achieved, infusions of metiamide $\left(4 \times 10^{-7}\right.$ or $2 \times 10^{-6} \mathrm{~mol} \mathrm{~kg}^{-1} \mathrm{~min}^{-1}$ ) caused further dosedependent displacement of the dose-response curve to the right (Figures 1 and 2). The displacements of the dose-response curves by metiamide in the experiments were not parallel, the slope of the curves being slightly less steep than the slope of the dose-response curve from untreated animals. The reason for this was that because of the long duration of the experiments, and because of the hypotensive effects of mepyramine $\left(2.5 \times 10^{-5} \mathrm{~mol} / \mathrm{kg}\right)$, the resting blood 


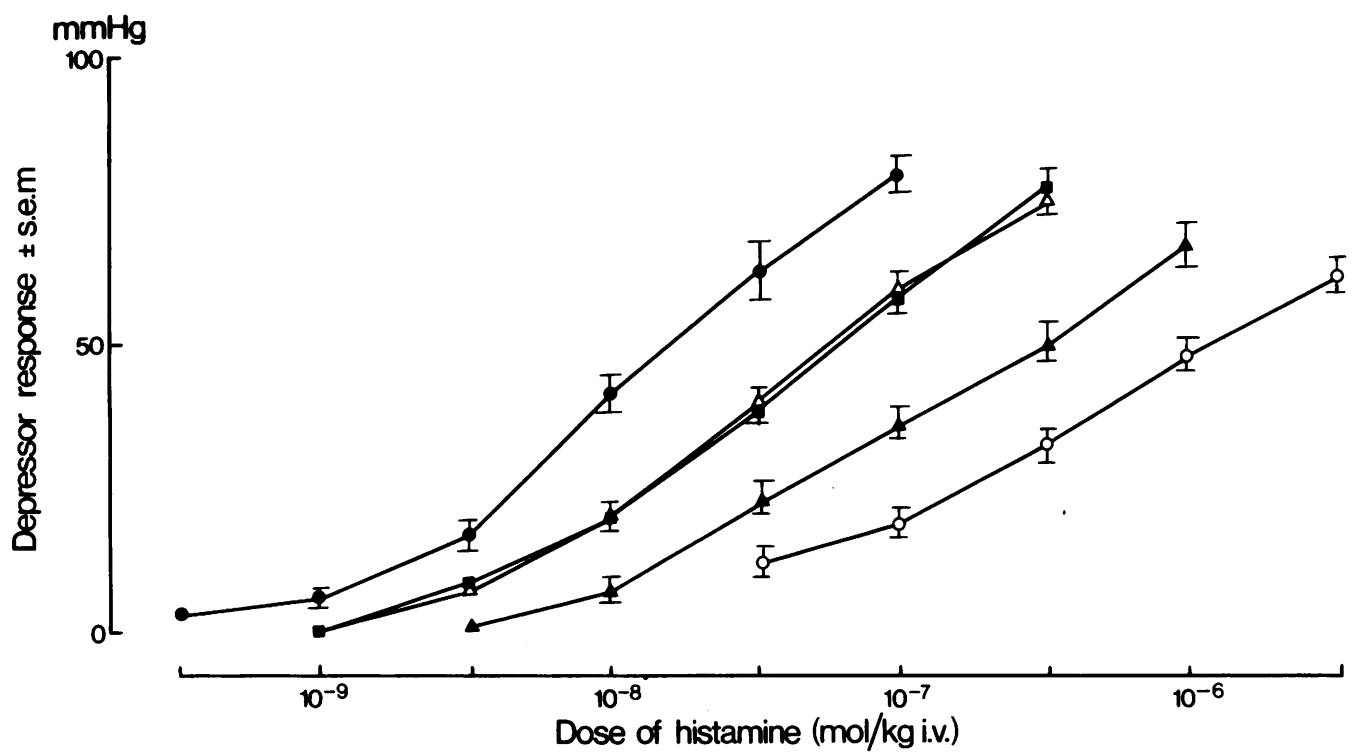

Figure 2 Anaesthetized dog blood pressure. Mean dose-response curves to histamine from five dogs. Responses to histamine prior to treatment with antagonists are indicated by $(\bullet)$. The dose-response curve was displaced to the right by mepyramine $2.5 \times 10^{-6} \mathrm{~mol} / \mathrm{kg}(-)$. Increasing the dose of mepyramine to $2.5 \times 10^{-5} \mathrm{~mol} / \mathrm{kg} \mathrm{caused}$ no further displacement of the dose-response curve $(\Delta)$. Metiamide $4 \times 10^{-7} \mathrm{~mol} \mathrm{~kg}^{-1} \mathrm{~min}^{-1}(\Delta)$, and $2 \times 10^{-6}$ mol $\mathrm{kg}^{-1} \mathrm{~min}^{-1}(0)$, in the presence of mepyramine caused further dose-dependent displacements of the histamine dose-response curve.

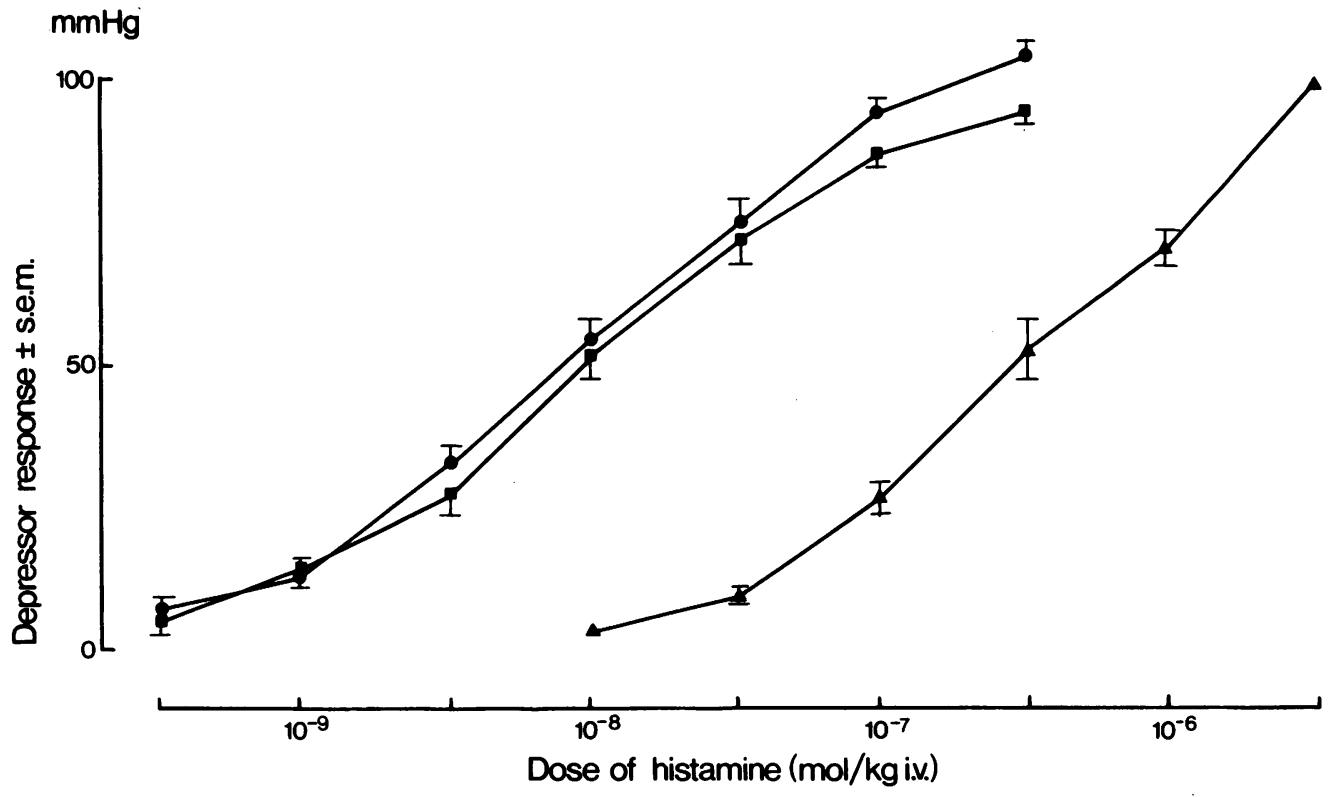

Figure 3 Anaesthetized dog blood pressure. Mean dose-response curves to histamine from five dogs. Responses to histamine prior to treatment with antagonists are indicated by $(\bullet)$. The dose-response curve was unaltered by metiamide $2 \times 10^{-6} \mathrm{~mol} \mathrm{~kg}^{-1} \mathrm{~min}^{-1}(\mathrm{a})$. In the presence of metiamide, mepyramine $2.5 \times 10^{-6} \mathrm{~mol} / \mathrm{kg}^{(\Delta)} \mathrm{caused}$ displacement of the dose-response curve. 


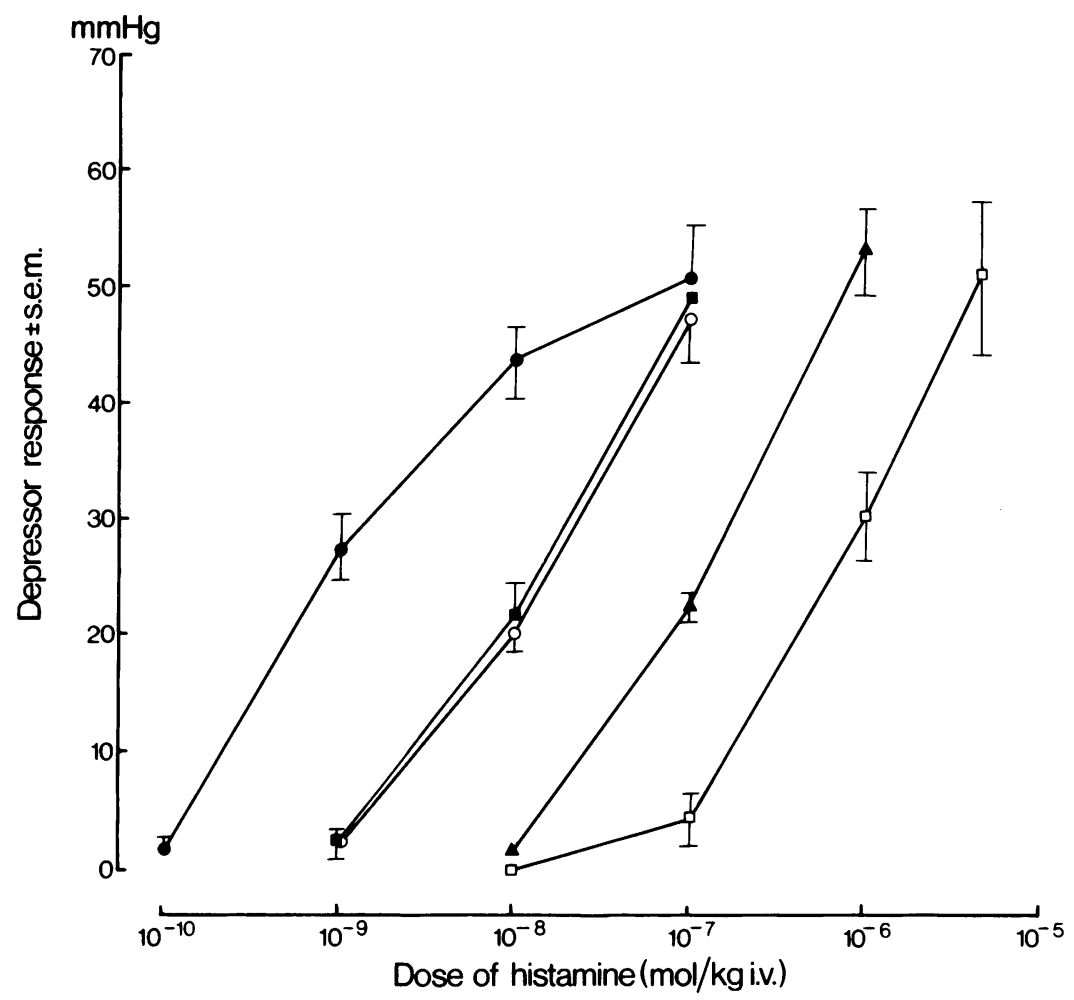

Figure 4 Anaesthetized cat blood pressure. Mean dose-response curves to histamine from five cats. Responses to histamine prior to antagonists are indicated by $(\bullet)$. The dose-response curve was displaced to the right by mepyramine $2.5 \times 10^{-5} \mathrm{~mol} / \mathrm{kg}$ (a). Mepyramine $5 \times 10^{-5} \mathrm{~mol} / \mathrm{kg}$ caused no further displacement of the dose-response curve (0). Metiamide $4 \times 10^{-7} \mathrm{~mol} \mathrm{~kg}^{-1} \mathrm{~min}^{-1}(\Delta)$ and $2 \times 10^{-6} \mathrm{~mol} \mathrm{~kg}^{-1} \mathrm{~min}^{-1}$ ( $\square$ ) caused further dose-dependent displacement, to the right, of the dose-response curve.

pressure at the end of the experiments was usually lower than at the start. Four additional short experiments were done to avoid this problem. Dose-response curves were obtained to three doses of histamine in untreated animals, and again after mepyramine $\left(5 \times 10^{-6} \mathrm{~mol} / \mathrm{kg}\right)$, in order to achieve a maximum shift in the dose-response curve, and during the infusion of metiamide $\left(4 \times 10^{-7} \mathrm{~mol}\right.$ $\left.\mathrm{kg}^{-1} \min ^{-1}\right)$ plus mepyramine $\left(5 \times 10^{-6} \mathrm{~mol} / \mathrm{kg}\right)$. The doses of histamine were chosen from the earlier experiments to lie on the linear part of the dose-response curve. In these shorter experiments there were parallel shifts in the dose-response curves after mepyramine, dose-ratio 7.1 (5.7-8.9, 95\% confidence limits) and after mepyramine plus metiamide, dose-ratio $16.3 \quad(13.3-20.1, \quad 95 \%$ confidence limits).

Metiamide alone $\left(2 \times 10^{-6} \mathrm{~mol} \mathrm{~kg}^{-1} \mathrm{~min}^{-1}\right)$ had little or no effect on the histamine dose-response curve (see Figure 3). Administration of mepyramine, $\left(2.5 \times 10^{-6} \mathrm{~mol} / \mathrm{kg}\right)$ during the continued infusion of metiamide, caused a parallel shift in the histamine dose-response curve with a doseratio of 42.0 (31.8-52.3, 95\% confidence limits) i.e. the shift in the dose-response curve caused by mepyramine $\left(2.5 \times 10^{-6} \mathrm{~mol} / \mathrm{kg}\right)$ was approximately 8-10 times greater during the infusion of metiamide than in its absence.

\section{Anaesthetized cats}

Histamine administered intravenously caused dose-dependent falls in blood pressure over the dose-range $1 \times 10^{-10}$ to $1 \times 10^{-7} \mathrm{~mol} / \mathrm{kg}$. In contrast to dogs, maximal depressor responses could usually be obtained after histamine $\left(1 \times 10^{-7} \mathrm{~mol} / \mathrm{kg}\right)$ with recovery of the resting blood pressure to the pre-injection level. In most cats, the depressor responses to the larger doses of histamine were followed by secondary pressor responses which were due to release of catecholamines from the adrenal medulla and 
other chromaffin tissues (Burn \& Dale, 1926). Unlike the depressor responses which were reproducible, the magnitude of the secondary pressor responses varied when the same dose of histamine was given repeatedly.

As in the dog, mepyramine $\left(2.5 \times 10^{-6} \mathrm{~mol} / \mathrm{kg}\right)$ displaced the histamine depressor dose-response curve to the right and abolished the secondary pressor responses. However and in contrast to dogs, the displacement of the histamine doseresponse curve in the cat was not parallel, the slope of the curve being steeper after mepyramine than in the untreated animals (Figure 4). The change in the slope of the dose-response curve appeared to be due to the abolition of histamine-induced catecholamine release by mepyramine (Emmelin \& Muren, 1949). In four experiments in which the effects of the catecholamines were prevented by pretreatment with phentolamine, $\left(1.6 \times 10^{-5} \mathrm{~mol} / \mathrm{kg}\right)$ and propranolol $\left(8.4 \times 10^{-6} \mathrm{~mol} / \mathrm{kg}\right)$ the displacement of the histamine dose-response curve caused by mepyramine was parallel. A maximum shift could be achieved by mepyramine $\left(2.5 \times 10^{-6} \mathrm{~mol} / \mathrm{kg}\right)$ with a dose-ratio of $8.6(4.7-15.8,95 \%$ confidence limits). When a maximum shift in the histamine dose-response curve caused by mepyramine had been achieved, metiamide $\left(4 \times 10^{-7}\right.$ or $2 \times 10^{-6}$ mol kg $\mathrm{min}^{-1}$ ) caused further dose-dependent displacements of the histamine dose-response curve (Figure 4). As in the dog metiamide $\left(2 \times 10^{-6} \mathrm{~mol} \mathrm{~kg}^{-1} \mathrm{~min}^{-1}\right)$ alone had no effect on the histamine dose-response curve although subsequent administration of mepyramine $\left(2.5 \times 10^{-6}, 8.3 \times 10^{-6}\right.$ and $\left.2.5 \times 10^{-5} \mathrm{~mol} / \mathrm{kg}\right)$ produced dose-dependent displacements of the dose-response curve to the right.

\section{Discussion}

Administration of histamine to cats and dogs results in a fall in systemic blood pressure. The purpose of this study was to analyze the depressor response to histamine in terms of the receptors involved. Prior to our study Staub (1939) had shown that the depressor response to a large dose of histamine, $6.6 \times 10^{-7} \mathrm{~mol} / \mathrm{kg}$, was refractory to histamine ( $\mathrm{H}_{1}$-receptor) antagonists of the Fourneau series. Subsequently Folkow et al. (1948) observed that the responses to small doses of histamine could be abolished by diphenhydramine and analogues of diphenhydramine but confirmed that the responses to larger doses of histamine were refractory to histamine ( $\mathrm{H}_{1}$-receptor) antagonists. Folkow et al. (1948) suggested that 'there are two types of receptors sensitive to histamine, only one of which can be blocked by benadryl (diphenhydramine) and related compounds'. Our findings establish the involvement of the two types of histamine receptor in the depressor response to histamine in the dog and cat.

In 1972 Black et al., showed that, in the cat, histamine responses that were refractory to $\mathrm{H}_{1}$-receptor blockade could be blocked by $\mathrm{H}_{2}$-receptor blockade, indicating the presence of cardiovascular $\mathrm{H}_{2}$-receptors and their involvement in these depressor responses.

In both species, mepyramine caused displacement to the right of the histamine dose-response curve, whereas metiamide alone did not displace the dose-response curve. In the dog, the displacement of the dose-response curve was parallel but it was not in the cat, unless there had been prior blockade of the responses to catecholamines released by histamine (Burn \& Dale, 1926). The release of catecholamines is reduced or abolished by mepyramine (Emmelin \& Muren, 1949). In untreated animals the catecholamines opposed the depressor response to histamine and the elevated catecholamine levels often persisted to elicit a secondary pressor response. Mepyramine simultaneously abolished the catecholamine release and reduced the depressor response to histamine. It is not, therefore, surprising that the displacement of the dose-response curve caused by mepyramine was not parallel unless there was prior adrenoceptor blockade. There are no quantitative data on catecholamine release in cats and dogs but it appears likely that greater release occurs in the cat than in the dog.

The displacement of the dose-response curves by mepyramine reached a maximum and this was achieved with similar dose-ratios in both dogs and cats. In both species once the maximum effect of mepyramine had been achieved further displacement of the histamine dose-response curve could be achieved by administration of metiamide. The displacement of the dose-response curve caused by metiamide was parallel indicating the competitive nature of histamine $\mathrm{H}_{2}$-receptor blockade by metiamide.

From these experiments it is clear that large displacements of the histamine dose-response curves can only be achieved by simultaneous administration of both an $\mathrm{H}_{1}$-receptor antagonist and an $\mathrm{H}_{2}$-receptor antagonist. Ariëns, van Rossum \& Simonis (1959) considered the theoretical dose-response curves likely to result from the interaction of one agonist with two independent receptor systems producing effects by means of a common effector system. This theory should apply to the situation studied in our experiments. One agonist, histamine, interacts 
with two independent receptors, histamine $\mathrm{H}_{1}$ and $\mathrm{H}_{2}$-receptors, to produce a common effect, a fall in blood pressure. As far as could be measured, the maximum responses which followed interaction with either receptor were comparable. Under these circumstances Ariëns et al. (1959) found that the shape of the dose-response curves varied with the values of the dissociation constant ratio for the agonist at the two receptors. When the value of the dissociation constant for receptor II was greater than the value for receptor I, then the shape of the dose-response curve was determined by the interaction of the agonist with receptor $I$, the effect of the interaction with receptor II being fully masked. The effect of interaction with receptor II could be unmasked by means of a competitive antagonist for the interaction of the agonist with receptor $I$.

Our experimental findings fit remarkably well into these theoretical curves, derived by Ariëns et al. (1959). The dose-response curve for histamine

\section{References}

ARJËNS, F.J., van ROSSUM, J.M. \& SIMONIS, A.M. (1959). A theoretical basis of molecular pharmacology. Part III: Interaction of one or two compounds with two independent receptor systems. Arzneim. Forsch., 6, 737-746.

BLACK, J.W., IUUNAN, W.A.M., DURANT, G.J., (;ANFLLIN, C.R. \& PARSONS, M.E. (1972). Definition and antagonism of histamine $\mathrm{H}_{2}$-receptors. Nature, Lond., 236, 385-390.

BLACK, J.W., DUNCAN, W.A.M., FMMFTT, J.C., GANELLIN, C.R., HESSELBO, T., PARSONS, M.E. \& WYLLIE, J.H. (1973). Metiamide -- an orally active histamine $\mathrm{H}_{2}$-receptor antagonist. Agents and Actions, 3, 133-137.

BURN, J.H. \& DALE, H.H. (1926). The vasodilator action of histamine and its physiological significance. J. Phy'siol. Lond., 61, 185-214.

DALE, H.H. \& LAIDLAW, P.P. (1910). The physiological action of beta-imidazolylethylamine. J. Physiol. lond., 41, 318-344. appears to be determined by the interaction of histamine with the $\mathrm{H}_{1}$-receptors and any effect resulting from interaction with the $\mathrm{H}_{2}$-receptors is masked. This is consistent with the failure of metiamide, a competitive antagonist of histamine at the $\mathrm{H}_{2}$-receptor, to modify the dose-response relation for histamine. The effects resulting from interaction with the histamine $\mathrm{H}_{2}$-receptors were revealed by treatment with mepyramine, a competitive antagonist of histamine at the $\mathrm{H}_{1}$-receptor. In the hypothetical situation described by Ariens et al. (1959) the shape of the dose-response curve was determined by the interaction of the agonist with the receptor having the smaller dissociation constant, in our experiments the interaction of histamine with the $\mathrm{H}_{1}$-receptors.

We are grateful to Mrs Helen liarrington, Mrs Ann Wonnacott and $\mathrm{Mr}$ Duncan Cameron for their valuable technical assistance.

EMMELIN, N. \& MUREN, A. (1949). Effects of anti-histamine compounds on the adrenaline liberation from the suprarenals. Acta. physiol. Scand., 17, 345-355.

FOLKOW, B., HAE(GFR, K. \& KAHLSON, G. (1948). Observations on reactive hyperaemia as related to histamine on drugs antagonising vasodilation induced by histamine and on vasodilator properties of adenosinetriphosphate. Acta. physiol. Scand., 15, 264-278.

OWEN, D.A.A. \& PARSONS, M.F. (1974). Histamine receptors in the cardiovascular system of the cat. $\mathrm{Br} . J$. Pharmac., 51, 123P-124P.

STAUB, A.M. (1939). Recherches sur quelques bases synthetiques antagonistes de l'histamine. Ann. Inst. Pasteur. 63, 400-436. 